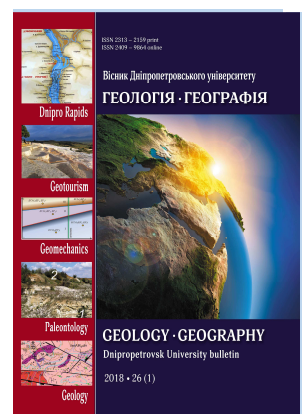

\section{Geology • Geography Dnipro university bulletin}

Volodymyr V. Manyuk

Journal home page: geology-dnu-dp.ua
ISSN 2313-2159 (print) ISSN 2409-9864(online)

Dniprop. Univer.bulletin. Geology, geography., 26(1), 121-134.

doi: $10.15421 / 111813$

\title{
Precambrian geological history of the Dnipro Rapids
}

\author{
Volodymyr V. Manyuk \\ Oles Honchar Dnipro National University,Ukraine,vgeoman@gmail.com
}

\author{
Received 10.01.2018 \\ Received in revised form 26.01.2018 \\ Accepted 15.02.2018
}

\begin{abstract}
This article provides a concise description of chronological sequence of Rapids in the Dnipro within the area between the cities Dnipro and Zaporizhia, their role in the maritime transport of the Dnipro, and the relationship between humans and the river during a number of historical epochs; it presents the role of the Dnipro Rapids, also known as the Porohy
\end{abstract} of the Dnipro, as unique natural formations in the great River Dnipro, which flows through three countries and cuts through the Ukraininan Crystalline Shield. The article analyzes the sequence of measures taken by the supporters of conservation of nature along the Dnipro Rapids area, representatives of nature-conservation organizations and all people interested in Dnipro Rapids and conservation of its unique natural heritage - beginning with founding "Dniprovski Porohy" National Geological Reserve in Zaporizhia Oblast in 1974 to organizing "Dniprovi Porohy" Regional Landscape Park on the territory between Stari Kodaky village and the border of Zaporizhia Oblast. This paper highlights the diversity of geological processes which have taken place over a long and dynamic geological history, described in the stone chronicle or rocks and minerals, and which formed the Dnipro Rapids, an object of interest of many generations to come. This article emphasizes the fact that the geological component of a valuable natural phenomenon was described for the first time only in the results of particular studies by Valerian Domger, who conducted his research for the building of Katerynynska Railway upon instructions from the Geological Committee from 1881 to 1884. The pegmatite, diabase, granite, syenite with peculiarities of their mineral composition, elements of bedding, described by V Domger for the Nenasytetsky and Lohanivsky and other Rapids and islands, were not the only phenomena which have disappeared beneath the Dnipro waters forever. The small quarries, where the young geologist described the Sarmatian limestones, left no signs of their existence and not a single outcrop of the limestone survived. Therefore, the routes of V O Domger, the discoverer of the Nikopol manganese deposits, Tomakivska fauna of the Mediterranean type and Mandrykivska fauna, one of the best preserved in the world, are of great historical value. Likewise, his field studies have still not lost their scientific significance. This paper succinctly describes the geological history of the area of the Dnipro Rapids and the oldest crystalline rocks of the Aul series and non-stratified formations of the Dnipropetrovsk and other natural complexes, involved in the formation of certain rapids.

Keywords: Dnipro rapids, Precambrian, Nature Preserve, migmatites, aplite-pegmatitic granite

\section{Докембрійська геологічна історія Дніпрових порогів}

\author{
Володимир В. Манюк
}

Дніпровський національний університет імені Олеся Гончара, Дніпро, е-таil: manuk-geо@mail.ru

Аннотація. Розглядається у стислій хронологічній послідовності проблема існування порогів на ділянці р. Дніпра від сучасного міста Дніпра до м. Запоріжжя, їх роль у судноплавстві по Дніпру і взагалі у співіснуванні людини і річки впродовж багатьох історичних епох. Висвітлюється роль Дніпрових порогів, як унікального природного створіння на величному Дніпрі, який несе свої води через три країни і прорізає Український кристалічний щит. Проаналізована послідовність дій прихильників збереження дикої природи Подніпров'я, представників природоохоронних організацій та всіх небайдужих до долі Порожистого Дніпра по збереженню унікальної природної спадщини від створення у 1974 році геологічного заказника загальнодержавного значення «Дніпровські пороги» в м. Запоріжжі до організації на території від с. Старі Кодаки до границі із Запорізькою областю Регіонального ландшафтного парку «Дніпрові пороги». Визначено, що саме різноманіття геологічних процесів, які діяли впродовж тривалої і бурхливої геологічної історії, записаної у кам'яному літописі або породах і мінералах, створило об’єкт захоплення багатьох поколінь - Дніпрові пороги. Підкреслюється, що геологічна складова яскравого природного явища була вперше висвітленою лише у результатах досліджень Валеріана Домгера, які виконувалися ним за дорученням Геолкому з 1881 по 1884 роки у з'язку з будівництвом Катерининської залізниці. Не тільки пегматити, діабази, граніти, сієніти з особливостями мінерального складу, елементами залягання, встановленими В. Домгером на Ненаситецькому, Лоханському та інших порогах та островах назавжди зникли під водами Дніпра, але й не залишилося жодних ознак невеликих кар'єрів, в яких молодший геолог Геолкому описав сарматські вапняки і відповідно немає зараз жодного виходу цих порід на поверхню. Тому маршрути першовідкривача Нікопольського родовища марганцю, томаківської фауни 
Середземноморського типу та однієї з кращої в світі мандриківської фауни В.О. Домгера мають не тільки велику історичну цінність, але певною мірою не втрачено й наукове значення його польових спостережень. Коротко охарактеризована геологічна історія регіону з точки зору тектоніки плит та надається аналіз геологічної будови Порожистого Дніпра 3 описом найдавніших кристалічних порід аульської серії та нестратифікованих утворень дніпропетровського та інших породних комплексів, які приймають участь у будові окремих конкретних порогів.

Ключові слова: дніпрові пороги, докембрій, геологічний заказник, мігматит, апліто-пегматоїдний граніт.

Introduction. The first projects focused on the problem of maritime transport in the Dnipro, Rapids emerged in the time of the Russian Empress Catherine the Great, but the dynamic waters of the river retreated only 120 later, after the great dam was between 1927 and 1932.

The Dnipro Rapids are one of the most unique natural formations on the great river Dnipro, which flows through three countries and cuts through the Ukrainian Crystalline Shield. The latter formed a barrier to the progress of the giant river so the Shield's Precambrian rocks crossed the calm flow of the water for a significant distance between Stari Kodaky village or Kodatsky Rapid (Maryan Dubiecki, 1900; Czołowski, 1926; Chaban, 2010) in the north and Velyky Luh in the south, where the Yavlen Zabora (Small Rapid) was located, and slightly above the flow was the Vilnyi (Vovchok, Hadiuchyi) Rapid, the last of the Rapids (Fig 1).

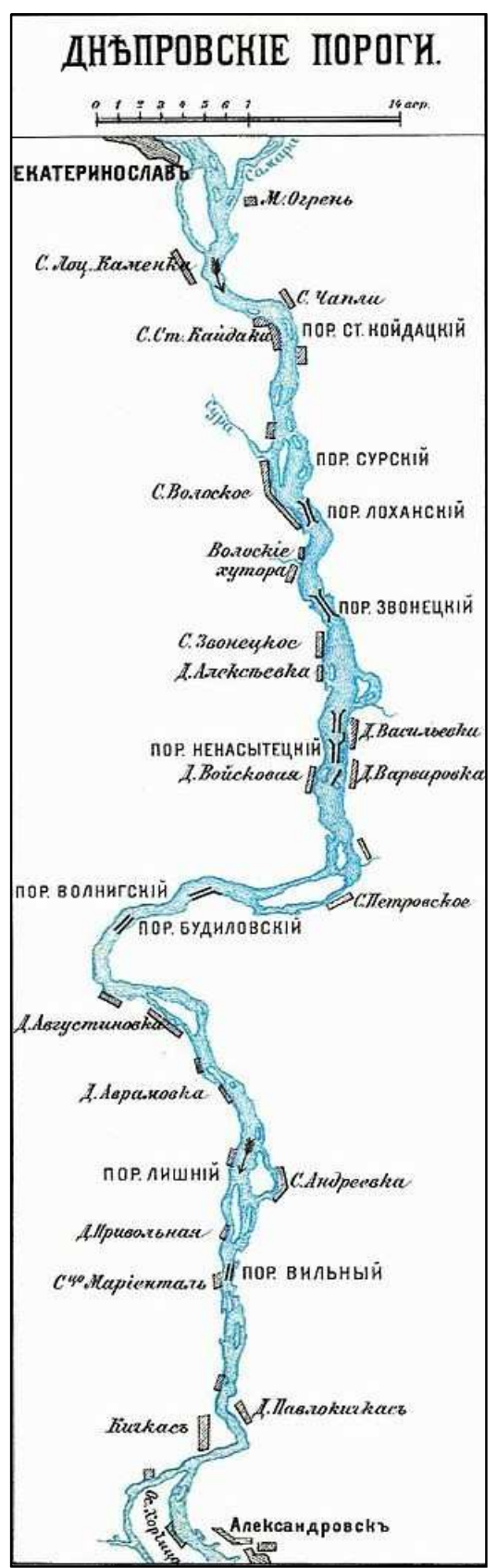

Fig. 1. The Dnipro Rapids in Encyclopedical dictionary of Brockhauz and Efron 
After the Dniprovska hydroelectric power station had been built and the Rapids had been flooded, their dynamic life was left in the past, but their extensions, occurring in the form of picturesque rock outcrops both on the Left and on the Right Bank of the Dnipro, create unique natural landscapes. Therefore, it is not surprising, that concerned people, scientists and nature-conservationists have been dreaming of preserving such a beautiful phenomenon for future generations. The first step to the dream coming true was the creation of the "Dniprovski Porohy" National
Preserve in Zaporizhia in 1974. This area of the Dnipro with Hortytsia island and adjacent territories covering an area of 1383 ha, despite its undisputable natural significance, does not belong to the Dnipro Rapids (in the traditional understanding) and is located $9 \mathrm{~km}$ to the south of the last Rapid. However, it organically fits into the Dnipro landscape, squeezed by rocky outcrops of crystalline rocks, the separate tops of which project above the water surface (Fig. 2).

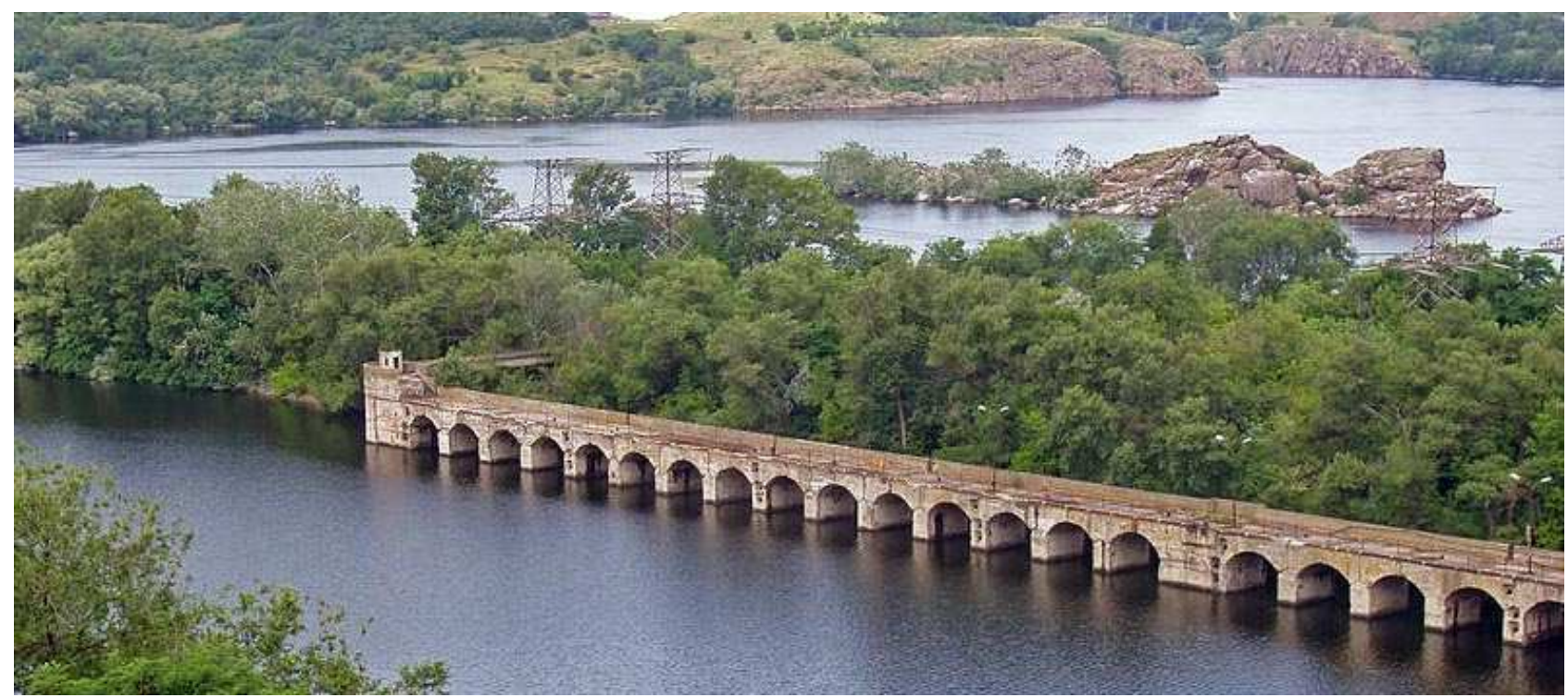

Fig. 2 "Dniprovski Porohy" Geological Preserve and Bayda island https://commons.wikimedia.org/w/index.php?curid=32688432

Almost 20 years later, due to the efforts of a small circle of specialists and nature-conservationists, particularly Hubkin A. A, zoologist, and Manyuk Vad. $\mathrm{V}$, geobatanist, a second step in preserving geo- and bio- diversity of the Rapids Dnipro was achieved, when a Regional Landscape Park was founded along a section of the Dnipro Rapids. After the project had been developed, it took 5 years of diligent work until the decision of the Dnipropetrovsk Oblast Administration №443-16/У from 25.092008 year created "Prydniprovskyi RLP (Regional Landscape Park) with a territory of 4917.9 ha. Despite great hopes and expectations, during the following 9 years, the Park existed only on paper (Fig. 3, 4).

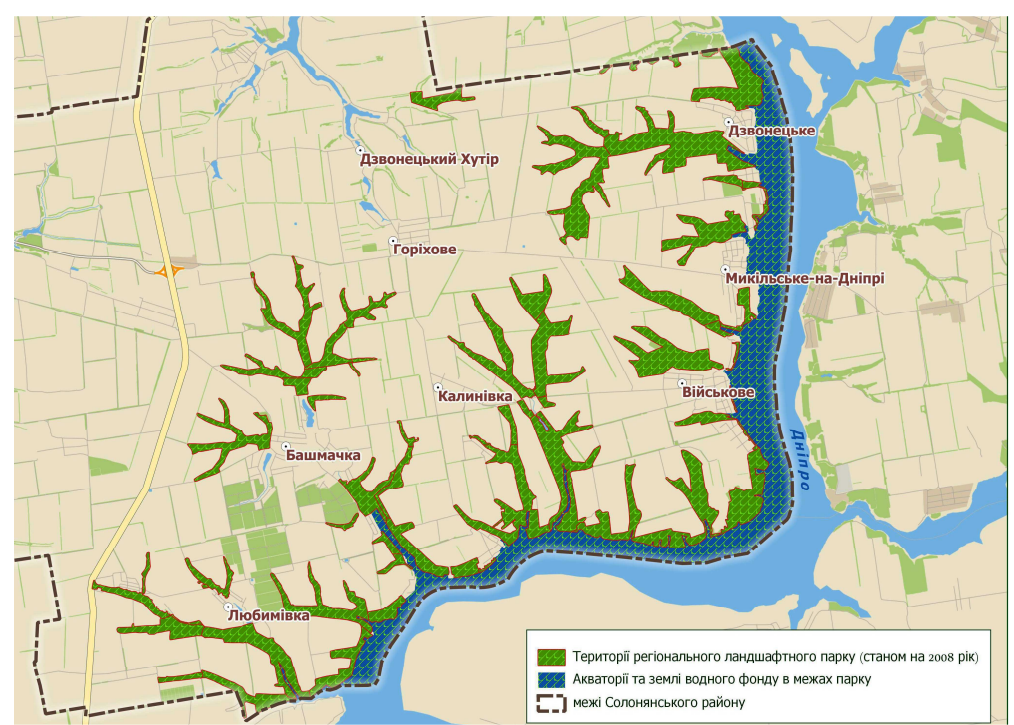

Fig. 3. "Prydniprovskyi" Regional Landscape Park, 


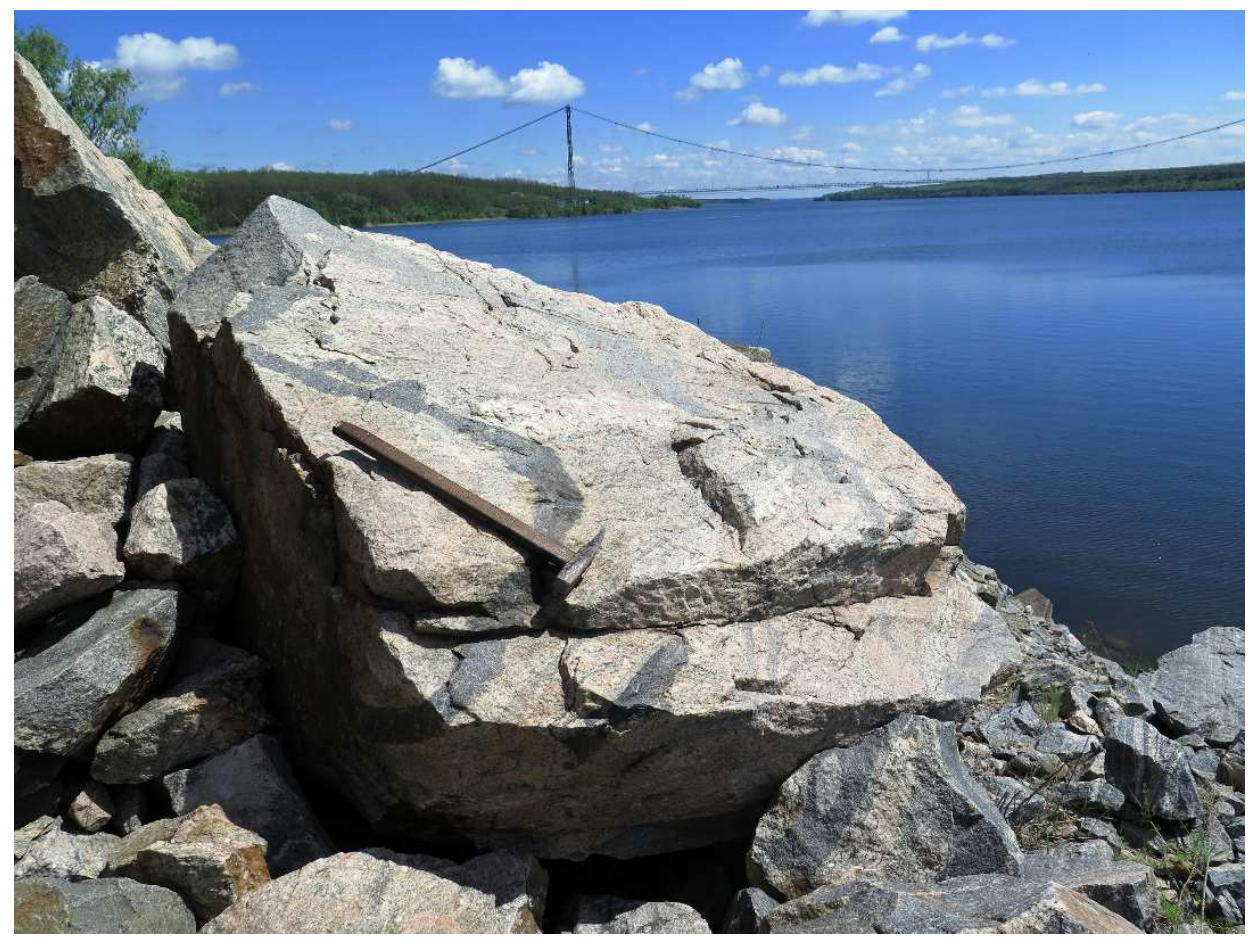

Fig. 4. Migmatites below the mouth of Bashmatchka (extension of Budylivsky Rapid)

The year of the rebirth of the park, or the year of its actual birth, but by the name of "Dnipro Rapids", was the year 2017, when after the initiative group's decisive action for updating the idea of actual preservation of this unique object of natural heritage, the idea was approved by all branches of government. That could be considered the third step towards preservation of wildlife in the territory, where the waters have been whirling around the famous Rapids. The current area of the park is $49 \mathrm{~km}^{2}$, but the full preservation of natural-historic landscape of the
Rapid Dnipro requires extending the territory to 150 $-200 \mathrm{~km}^{2}$ with further potential of reorganizing it into a National Natural Park. The Oblast Administration has created a municipal institution for the park's management, the tasks of which include preserving the geological heritage, natural diversity of the flora and fauna, ecosystem and landscapes of the Rapid Dnipro, conducting scientific monitoring and ecological education, developing different directions of tourism, including geotourism as the priority sphere (Fig. 5).

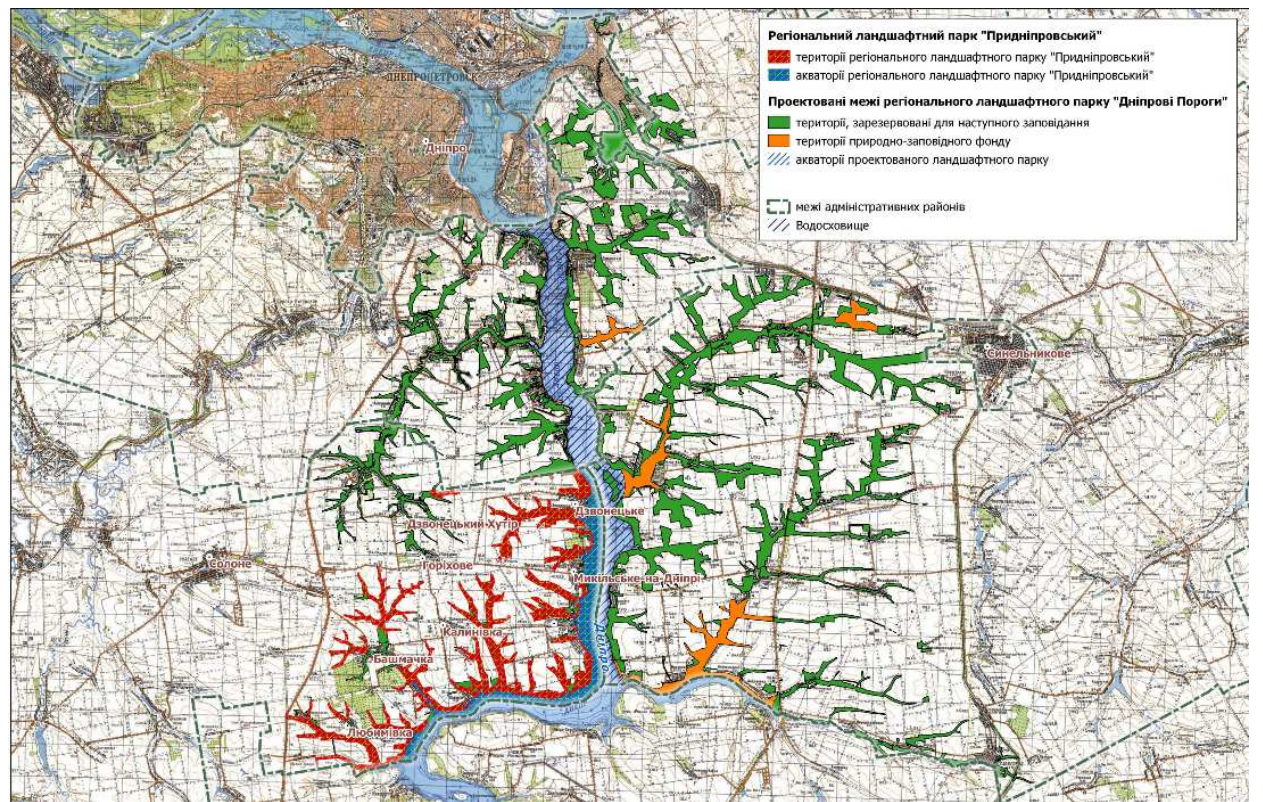

Fig. 5 Current and projected borders of the "Dniprovi Porohy" Regional Landscape Park 
The diversity of geological processes, which occurred over a long and dynamic geological history, embedded in the stone chronicles and minerals have created the Dnipro Rapids, an object of interest to many generations. Perhaps, the first person to hint at the Dnipro Rapids was Herodotus, who mentioned them in V century B. C. in Halicarnassus, he wrote: "The (Scythians) Tsars are buried in the area called Herros, where maritime transport floats on the Borysthenes (Dnipro)". It is believed that the first written source, which mentions the Dnipro Rapids, is "On the Administration of the Empire", the work by Constantine VII Porphyrogennetos, the Byzantine Emperor (between 943 and 952). The 9th Chapter contains description of The trade route from the Varangians to the Greeks and the seven Dnipro Rapids (Constantine VII Porphyrogennetos, 1991; Jordan, Robert Paul, 1985; Dolukhanov, 1996.). Later, the rocky outcrops of the Borysthenes Rapids were mentioned in 1660 by Guillaume Levasseur de Beauplan, a French engineer and military cartographer of Polish descent, in his work "Description de l'Ukranie depuis les confins de la Moscovie jusqu'avx limites de la Transylvanie". He wrote: "To exactly define the Porohy, I will say that Porohy is a Rus' word, which means a stone rock; these Porohy resemble chains of rocks, stretched across the River, including some that remain underwater, others are seen on the surface, and others rise above the water to 8 to 10 feet height". (Boplan, 2005)

The greatness of the Rapids leaves no visitors indifferent, though its striking geological component was for the first time described in the results of the studies conducted by Valirian Domger, who was conducting his surveys for the building of Katerynynska Railway (upon instructions from the Geological Committee) from 1881 to 1884 . Many things could be said about the historical significance of the survey routes taken by the discoverer of the Nikopol manganese deposits, Tomakivska fauna of the Mediterranean type and Mandrykivska fauna, one of the best preserved in the world. Likewise, his field studies still have not lost their scientific significance. The pegmatite, diabase, granite, syenite their with pecu- liarities of mineral composition, elements of bedding, described by V Domger for the Nenasytetsky and Lohanivsky and other Rapids and islands, are not the only phenomenon, which have disappeared under the Dnipro waters for ever. The small quarries where the young geologist described the Sarmatian limestones with Mactra podolica, Cardium obsoletum, and C. fitoni, left no signs of their existence and not a single outcrop of the limestone survived. Numerous geological studies both in the Rapids section of the Dnipro and the surrounding territories were conducted during Soviet times. A list of these works and their short description would turn this short report into an impressive monograph. However, the aim of this study is providing a short provisional description of the geological structure of recently created "Dniprovi Porohy" RLP using the materials of the most recent geological surveys, conducted with the author's participation and geological routes of 2017 (Shpylchak, Manyuk, Sukach, and Nekriach, 2007).

The park's territory occupies the central part of the Serednodniprovsky Megablock of the Ukrainian Shield, solid crystalline rocks of which have been resisting the Dnipro on its way to the Black Sea for approximately 3.5 mil years after the last Pontian marine transgression. The Serednodniprovsky block is a block-dome structure of Precambrian basement, limited by the Kryvorizko-Kremenchutska (on the west) and Orihovo-Pavlohradska (on the east) sutures from the perspective of supporters of the mobilism theory, or deep faults according to fixism supporters. Mentioning the ancient history of the Serednodniprovsky Megablock formation, there is a presumption that the linearly extended folding forms developed as a result of a collision of lithosphere blocks. Further the folding was altered as a result of domal elevations of granitoids. The area with green stone granite in the Middle Prydniprovia is considered an Archean riftogenous basin (Fig. 6). The fact that it was a spreading riftogenous basin is proved by the ultrabasite-mafite composition of the greater part of the Konkska series. Therefore, we are dealing with the remains of the oceanic core of that time. 


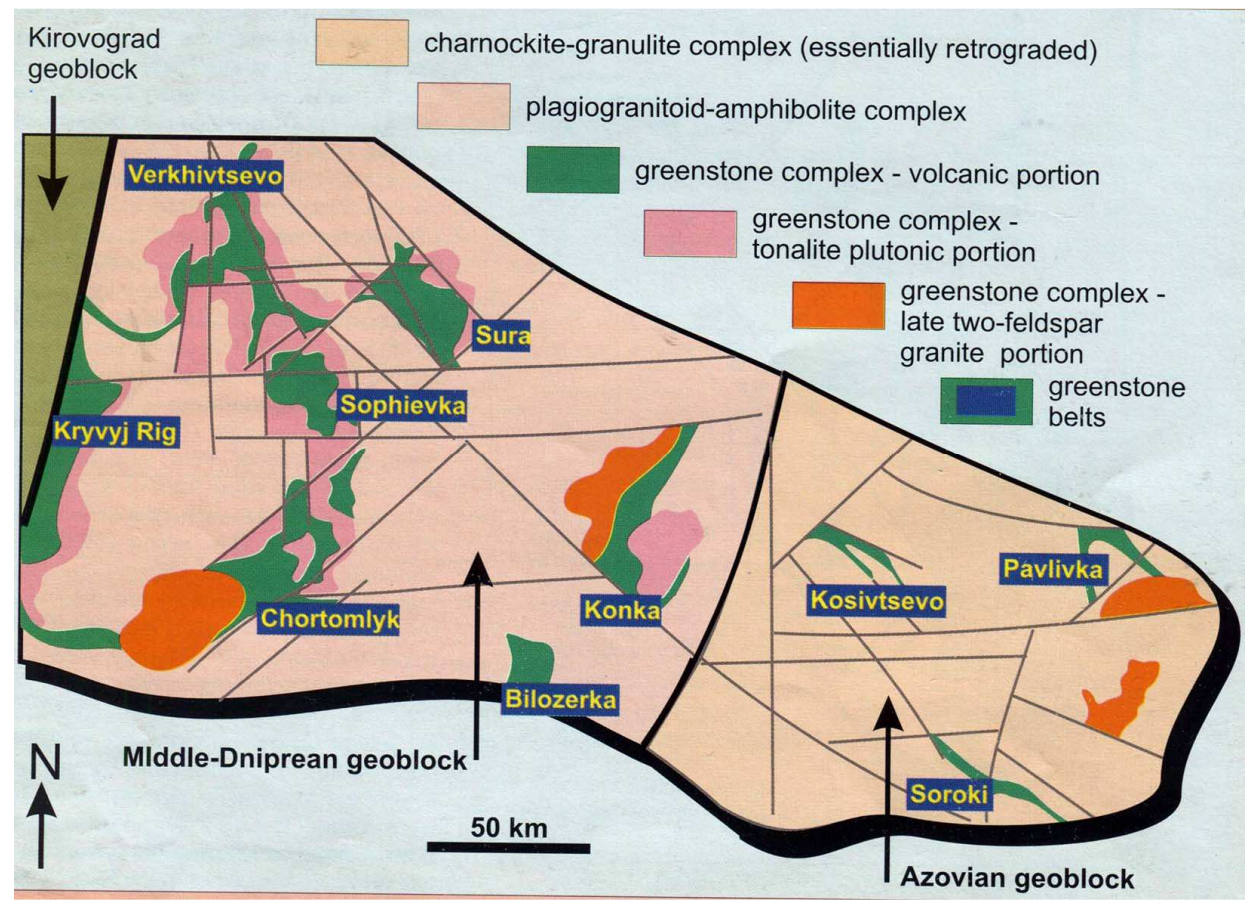

Fig. 6 Tectonic structure of the Serednodniprovsky Megablock of the Ukrainian Shield.

The geological structure of the area includes the rocks of the period from early Archean eon to Quaternary period. The oldest rocks of not only the Dnipro Rapids, but of the whole Ukrainian Shield, are crystalline schists, amphibolites, plagiogneisses of the Slavhorodska stratum of Paleoarchean rocks). They have a limited distribution within the Bashmachkynska Bank (Vovnihy village) near Ilarionovo and form the Dzvonetsko-Pavlinska Bank (Mohyla Mayorova Kurgan). In the latter, they are represented by amphibole-biotite pyroxene-bearing plagiogneisses, which outcrop in the valley of the Dnipro. A distinctive peculiarity of the stratum is occurrence in its section of a significant number of small stock-like bodies of gabbro, more seldom bodies of ultrabasites, which belong to the intrusive Oleksandrivsky complex. According to the data of additional geological mapping at a scale of 1:200 000 conducted in 2007 (Shpylchak, Manyuk, Sukach, and Nekriach, 2007) the right bank of the Dnipro in the pre-mouth area of the Bashmachka Ravine and the Quarry, which is slightly to the south from the Ravine, has numerous buttes of green stone rocks of the Slavhorodska stratum with xenoliths of metamorphic amphibolites of Oleksandrivsky complex (Fig. 7). Plagiomigmatites, which bear xenoliths, are characterized by high texture diversity. According to the proportion of bright (neosoms) to dark (paleosoms) component, this texture comprises striped (layer-by-layer), lenticular, ramified, reticulated (dictionites), breccia-like, block mass (agmatites), ptigmatite plicate, folded, spotted (taxite) types of migmatite (Fig. 8, 9).

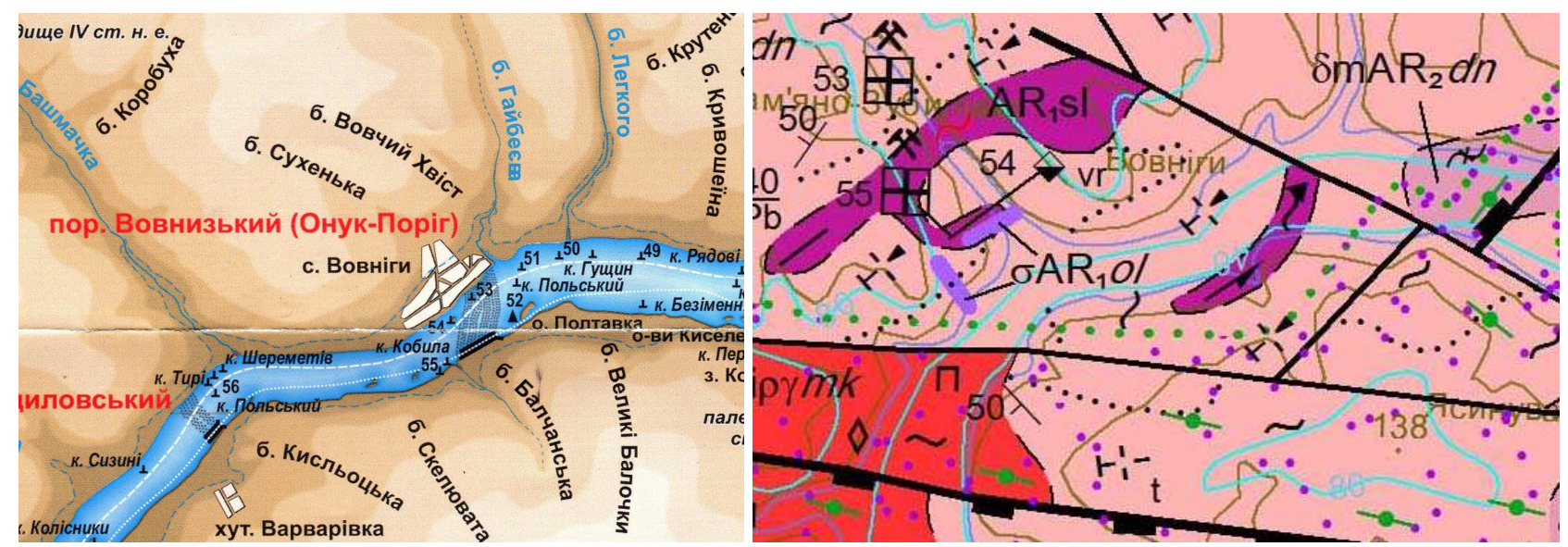

Fig. 7. The Vovnyzky Rapid on "The Dnipro Rapids" map by O. Vlasov and on a geological map. 

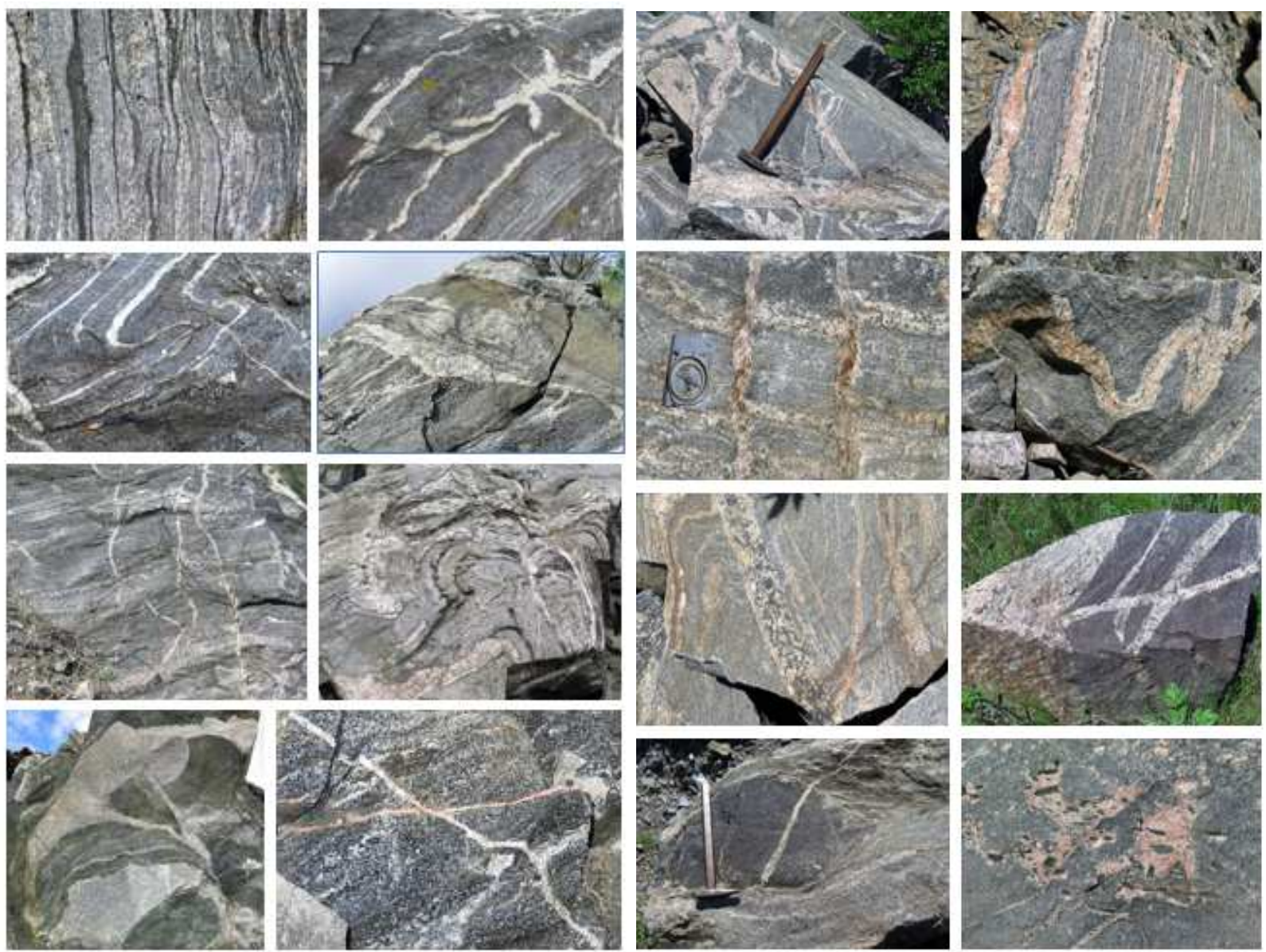

Fig. 8, 9 Textures of plagiomagmatites with xenolithes of gabbro-amphibolites in the mouth of the Bashmachka Ravine

Under a microscope, pyroxene-bearing crystalline schists can be seen with a granoblastic, lepidegranoblastic structure and the following mineral composition (in \%): hypersthenes - 0-30, diopside $0-15$, amphiboles $-0-40$, biotite -0.5 , plagioclase (oligoclase-andesine, seldom andesine- labradorite) - 45-70, quartz - 0-5; accessory - apatite, magnetite, ilmenite; secondary - chlorites, epidote. Biotite and biotite-amphibole plagiogneisses are rocks of grey and dark grey color, fine- and average grained and of striped or gneiss-like texture. They have outcrops in the shore zone of the Dnipro. The absolute age of the rocks of the Slavhorodska stratum is clearly established in the Rybalsky Quarry, it equals 3 bn years.

The rocks of Bazavlutska stratum are less common, and the last in the section of the Aul series. They are structurally tributary to peripheral parts of the Novooleksandrivsky dome and the axis of Mykilska syncline (Osokorivka River). Outcrops of the stratum rocks occur in the area of Lubymivka village and along the banks of the Dnipro. Mostly, it is out of scale lenticular bodies, which have been preserved from the granitization, dozens of meters in thickness, and up to $100 \mathrm{~m}$, and occasionally hundreds of meters long. The compound of the stratum is pretty monotonous: biotite, biotite-amphibole and amphibole gneisses, and tributary crystalline schists of the main compound and amphibolites. The rocks of the Bazavlutska stratum are involved in the structure of the flooded islands Piskuvaty and Dubovy, located in a bend of the Dnipro in the place where the Ploska Osokorivka flows into the Dnipro and the Dubova Ravine begins (Fig. 10). The absolute age of the rocks of the Bazavlutska stratum is over 3.2 bn years. 


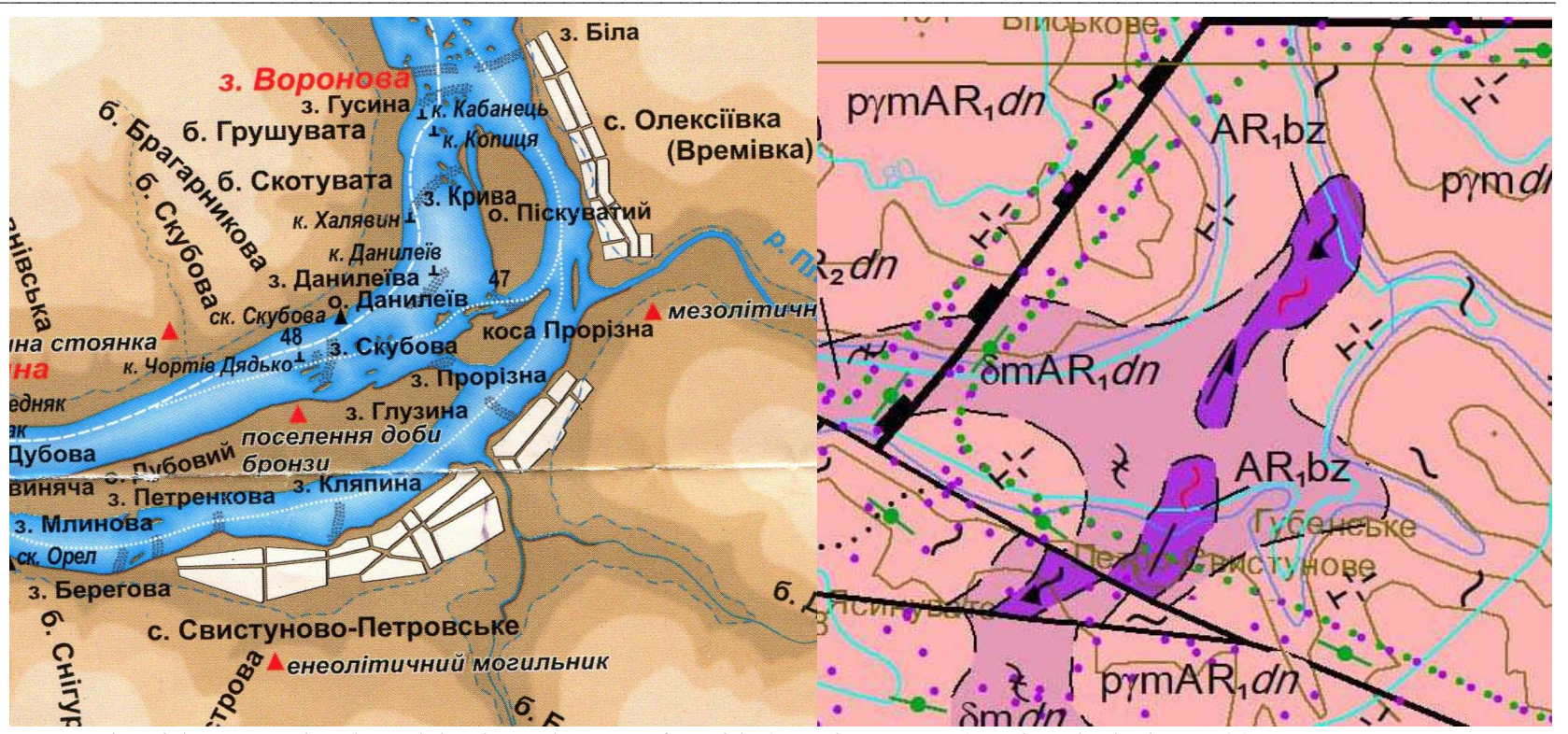

Fig. 10 The Piskuvaty and Dubovy islands on the map of Rapids (1 - Vlasov, 2016) and geological map (2)

The next long period of time is the Mesoarchean era (3.2 - 2.8 bn years), represented by the complexes dated before the green stone stage: intrusive Oleksandrivsky basite-ultrabasite and Dnipropetrovsky ultrametamorphic paleogranitoid complex, which covers the largest area. The post-green-stone group of the complexes includes intrusive basite-ultrabasite, autochthonous and parautochthonous two feldspar granites of the Demurynsky and Mokromoskovsky complexes. The Oleksandrivsky basiteultrabasite complex $\left(\mathbf{A} \mathbf{R}_{1} \mathbf{O l}\right)$ is represented mostly by metamorphic gabbroids. They form intrusive bodies of stock type with oval shape, more seldom rounded shape, and in area rarely larger than 1 square $\mathrm{km}$. In 2007, in the pre-mouth part of the Bashmachka Ravine in the abovementioned quarry, V. V. Sukach discovered and studied buttes of alkaline gabbro-amphibolites of lenticular, oval and cuneiform shape peculiar to the Oleksandrivsky complex (Sukach, 2007). Among the ultrametamorphic rocks of the pre-green-stone Aul complex, gabbroamphibolites are distinctive due to their dark grey color, mostly average-grained structure and massive, insignificantly schist texture (Fig. 11).

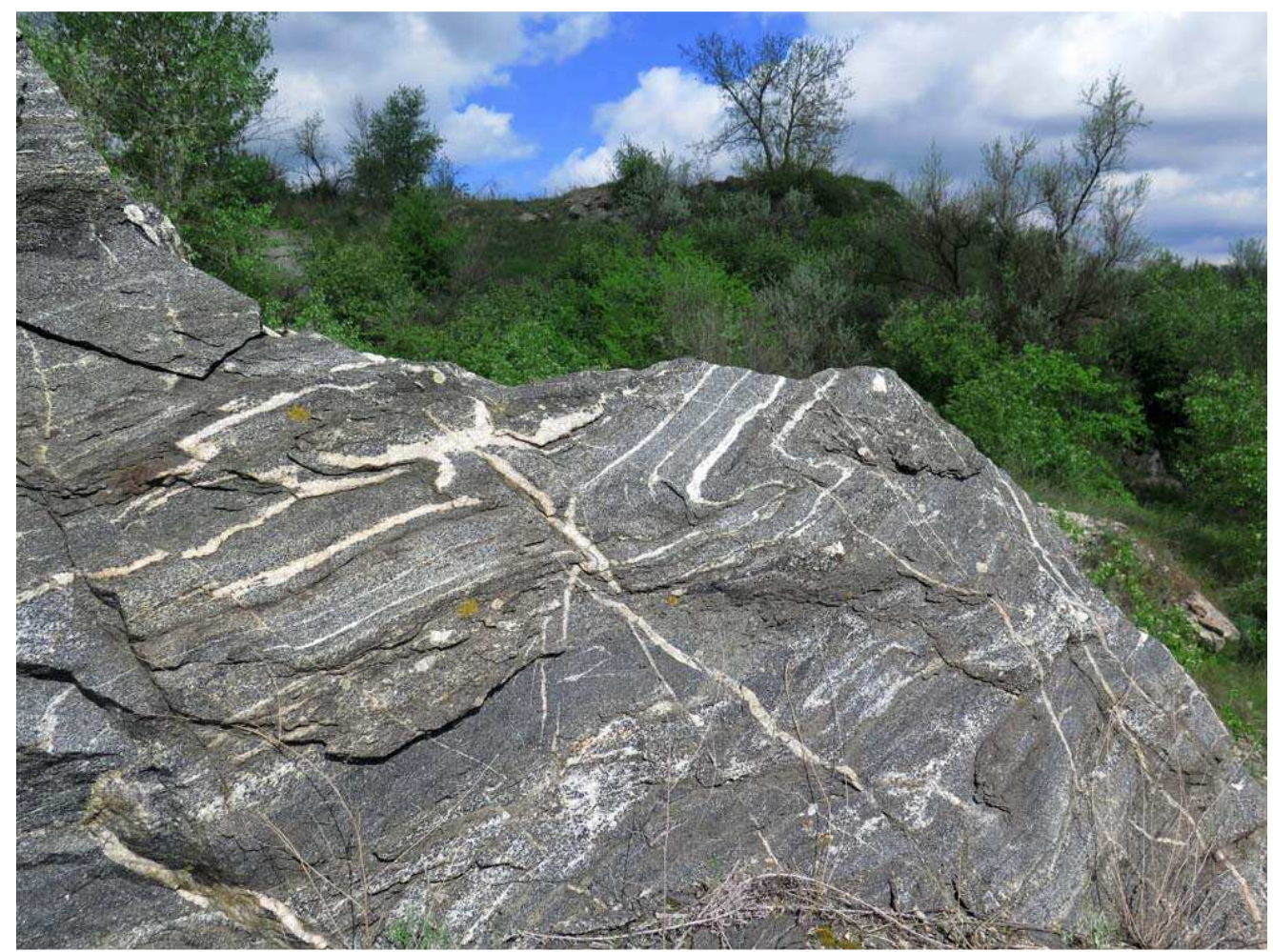

Fig. 11 Xenolithes of migmatized gabbro-amphibolites near the mouth of the Bashmachka river 
Despite the deep ultrametamorphic transformations of the enclosing rocks (gneiss and crystalline schists of the Aul formation), metagabbroids have sufficiently avoided migmatization due to their natural physical-chemical resistance to ultrametamorphism. V. V. Sukach considers that the discovered relics of intrusion of sub-alkaline gabbroids manifest the final stages of ultrametamorphism and the beginning of the formation of green stone structures within the Middle Prydniprovia. Similar rocks have also outcrops on the left bank of the Dnipro, in the area of
Dibrove village, where they form a butte, which is over $100 \mathrm{~m}$ high, and smaller xenolithes among plagiogranitoids. Therefore, it is possible that these peculiar rocks also take part in the formation of the Budylivsky Rapid, which is located almost in the mouth of the Bashmachka Ravine, and formation of the Vovnyzky Rapid, which is located slightly higher, near the mouth of the Habeieva Ravine, and also formation of the Lohanivsky and Strilchy Rapids in the area of Dibrova and Maiorka villages (Fig. $7,12)$.
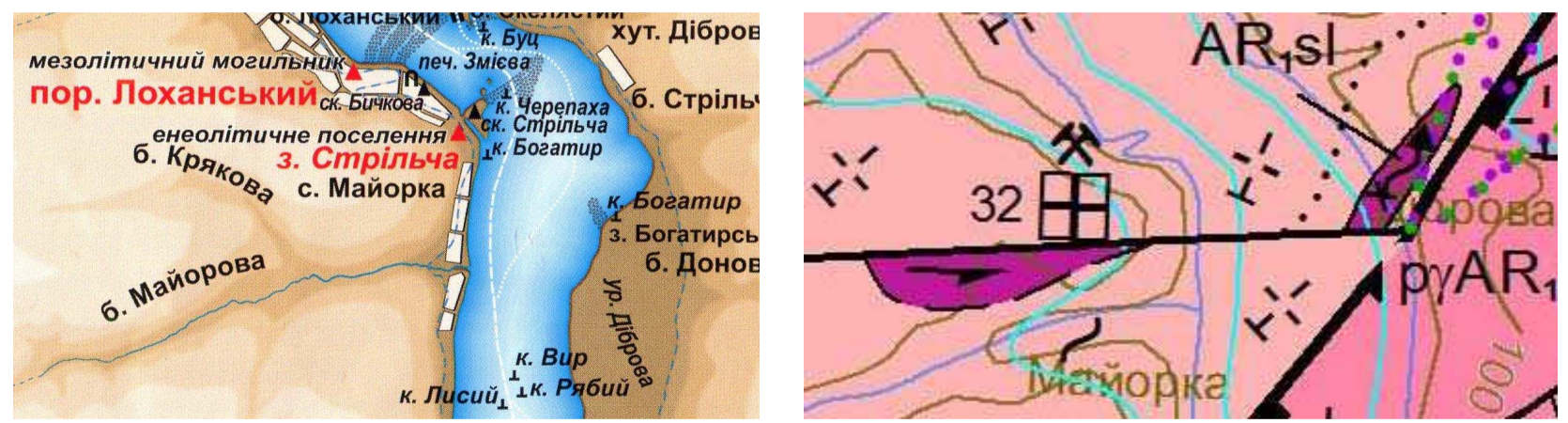

Fig. 12 Lohanivsky Rapid and Strilcha Zabora (Little Rapid) on the map of the Rapids (Yavornytsky, 1928) and the map of Precambrian rocks.

\section{Plagiogranitoides of the Dnipropetrovsky com-} $\operatorname{plex}\left(\mathbf{A R}_{\mathbf{1}} \boldsymbol{d n}\right)$ are the most common rocks on the territory of the projected park. Mostly these are plagioclasic autochthonous and anatectic granitoids, the greater part of which consists of plagiomigmatites, biotite plagiogranites and amphibole-biotite plagiogranites. The edges of plagiomigmatites and plagiogranites are represented by a dense association of thin-striped, unclearly-striped, spotted formations and massive rocks of typical plutonic type, interrelated by complicated inter-transformations. This association of rocks forms a giant territory along the banks of the Dnipro: on the right bank - at the section between the villages Voloske and Vovnihy, on the left bank - from Stari Kodaky village on the north side to Petro-Muhailivka village on the south side (the basins of the Tatarka, Vorony, and Ploska Osokorivka rivers). A distinctive characteristic of these rocks is the presence of quartzitic, quartz-feldspar and aplite-pegmatoide veinlets and veins, which occur mostly as cross-cutting veins, less often layerby-layer. V. Domger made interesting observations: "In the upper end of the settlement (Volnihy village in the Domger's text is currently Vovnihy), near the mouth of the Habeieva Ravine and slightly higher, near a former manorial garden, there is a significant layer of white quartz, which forms a big solid hill, with a direction which corresponds to the rocks' stretching, i.e. WNW h 7,5. Quartz stretches down to the Habeieva Ravine and appears on the bank of the Dnipro as two separate ridges (Domger, 1902). The structure of the rocks is granoblastic with elements of porphyry- and lepide-blastic structures. The mineral composition of the migmatites is rather simple (in \%): plagioclase (oligoclase) 40-60, quartz 25-35 and biotite, the content of which is $25-30$ in paleosom, and 6-10\% in neosom. Plagioclase is often replaced with potassium feldspar. Significantly less common diorite-like plagiomigmatites $\left(\delta \mathrm{m} \mathrm{AR}_{2} \mathrm{dn}\right)$ are considered a product of granitization of basites of the Slavhorodska stratum and the Oleksandrivsky complex; this is indicated by narrow spatial interrelations and gradual transitions between them (Shpylchak, Maniuk, Sukach, and Nekriach, 2007). The largest areas of diorite-like plagiomigmatites are located in the area of the Nenasytets Rapid and in a bend of the Dnipro, where the Dubovy Island and a few rapids were located (Fig. 10-b). Biotite amphibole-biotite tonalites $\left(\operatorname{tnAR}_{2} \mathrm{dn}\right)$ (Chaplynsky quarry), quartzitic biotite-amphibole diorites, and of amphibole of, rarely pyroxene-bearing type (q $\delta$ $\mathrm{AR}_{2} \mathrm{dn}$ ) occur in a subordinate quantity. The latter form a small Yambuzky massif and outcrops on the south suburb of the city Dnipro on both banks of the Dnipro, where it stretches in a submeridional direction and stretches more than $10 \mathrm{~km}$ along the river. Macroscopically quarzitic diorites - green-grey, dark-grey average-, rarely coarse-grained rocks with massive, spotted, rarely spotted-striped textures and such mineral composition (in \%): plagioclase (№ 2436) - 50-75, potassium feldspar - 0-15, amphibole $5-20$, biotite - from single grains to 10 , pyroxene (diopside, rarely hypersthenes, ) $-0-5$, quartz - mostly $8-20$, magnetite and ilmenite $-1-9$, apatite, zircon, orthite, sphene. The density of quartzitic diorites - 
$2.84 \mathrm{~g} / \mathrm{cm}^{3}$; magnetic susceptibility is significantly diverse: 130 to $2000 \chi\left(4 \pi \times 10^{-6}\right.$ units $\left.\mathrm{CI}\right)$.

The absolute age of the rocks is over $2.7-3$ bn years. All rapids, except the Lyshniy and Vilny Rapids (i.e. 7 of 9) are formed mostly by the rocks of the
Dnipropetrovsky complex and insignificantly by the rocks of Slavhorodska and Bazavlutska stratum, the Oleksandrivsky and Demurynsky complexes (Fig. $13,14)$.

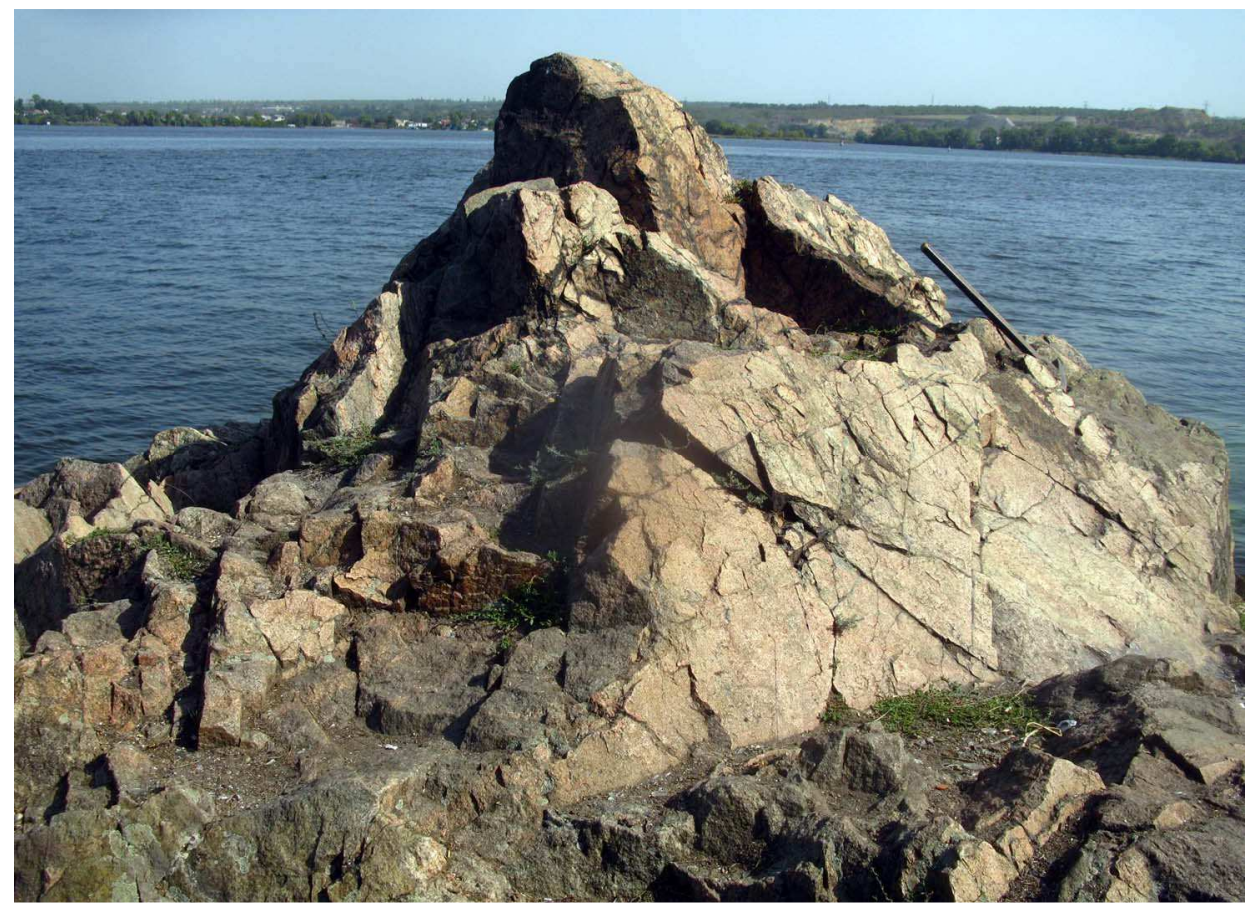

Fig. 13 Outcrops of biotite plagiomigmatites near the Kodachok Island

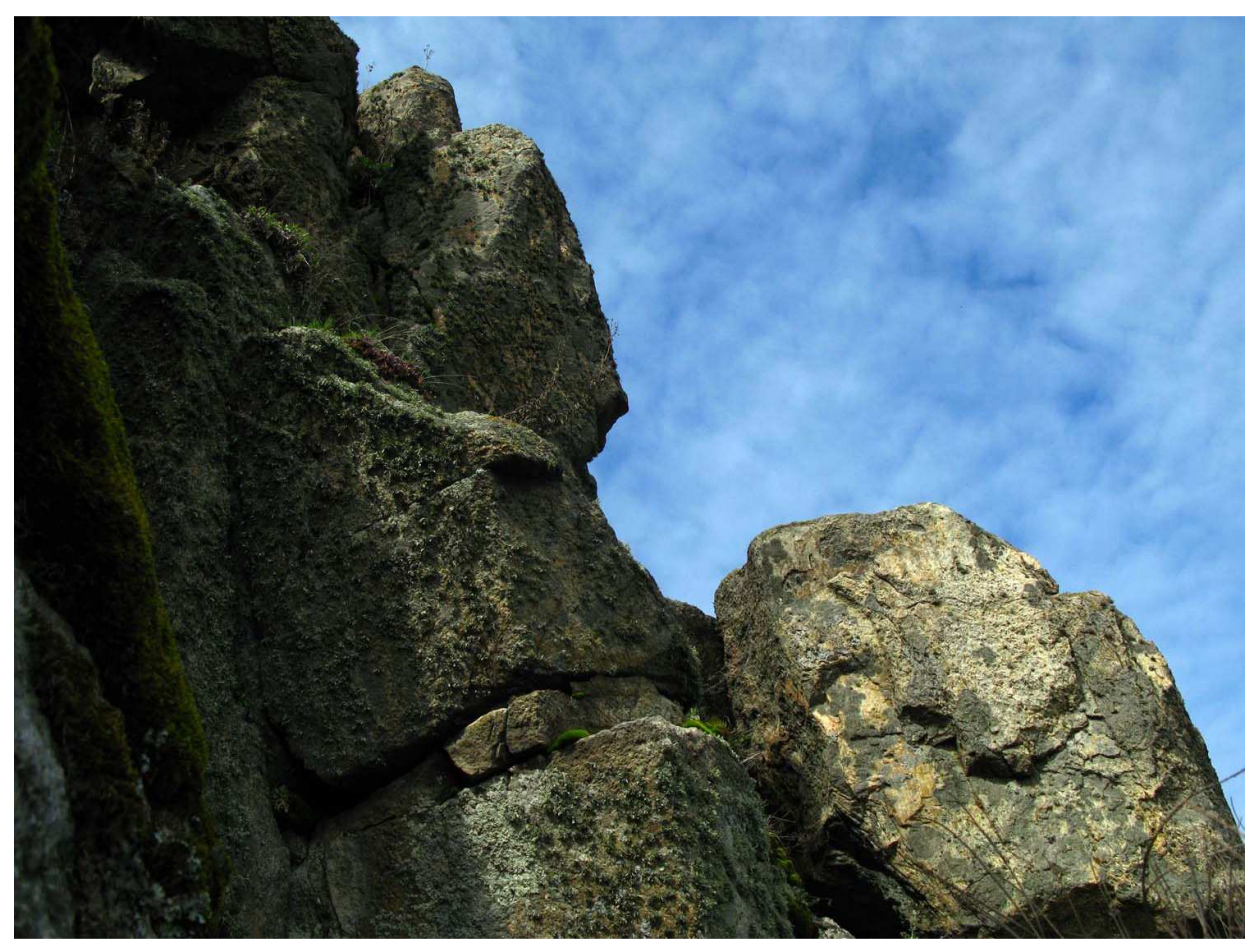

Fig. 14 Quartzitic diorites of the Yamburzky massif on the south of the city Dnipro

The Demurynsky complex includes autochthonous two feldspar granitoids, the genesis of which is considered related to potassium metasomatism of plagiogranitoids of the Dnipropetrovsky complex. It is represented porphyryblastic granites, biotite granodiorite, seldom migmatites, which form isometric or stretched, rarely irregular forms of the structures of an area of 5-30 $\mathrm{km}^{2}$. The rocks of the Demurynsky complex have outcrops on the right bank of the Dnipro between Oleksiivka and Viiskove villages. On this section of the bank, the waters of the Dnipro buried the Nenasytets Rapid (Did-Porih, Revuchy), 
the largest and the oldest Rapid, according to the people who saw it; its structure includes 12 benches (narrow rocky ridges which crossed the River), and every one had its name (Yavornytsky, 1928) and was formed rather by all rocks of the Demurynsky complex (Fig. 15).

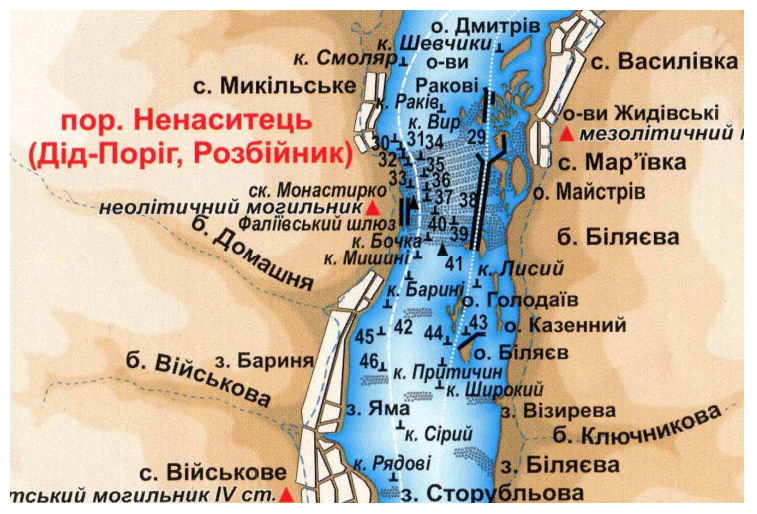

a

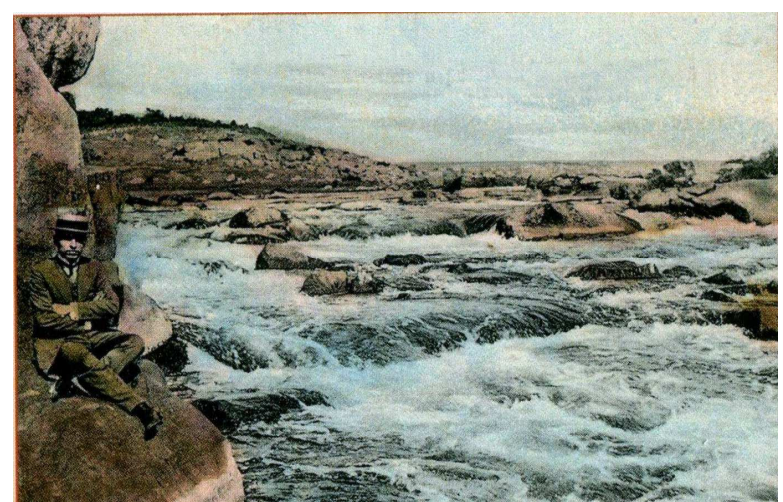

b

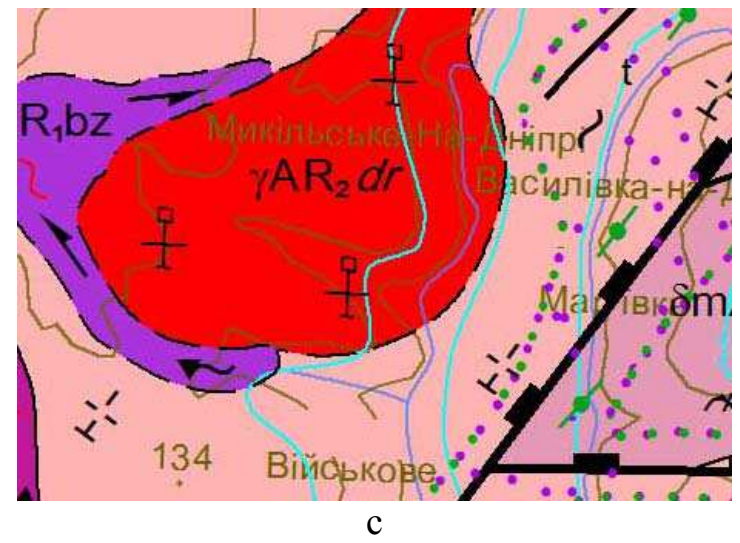

Fig. 15 Nenasytets Rapid on the map of the Rapids by O. Vlasov (a), on the image of 2010 (b) and on the map of Precambrian rocks (c).

Specific biotite-hornblende porphyroblastic migmatites, which develop along the plagiogranits with xenolithes of amphibolites, have outcrops in the area of Voloske village. The outcrops are grey-pink porphyryblastic rocks with spotted distribution of biotite and hornblende. Porphyryblasts are represented by microcline, which in the form of regular ellipse formations of $1.5-2 \mathrm{~cm}$ is distributed throughout the rock. The south part of the village with natural outcrops and the abandoned quarry of the cliffs, formed by these rocks, has conservation status as "Granite Cliffs" natural relic. However, they are more familiar as "the Voloski Cliffs" or "the Strilcha Zabora (Little Rapid, Cliff”) (Fig. 16).

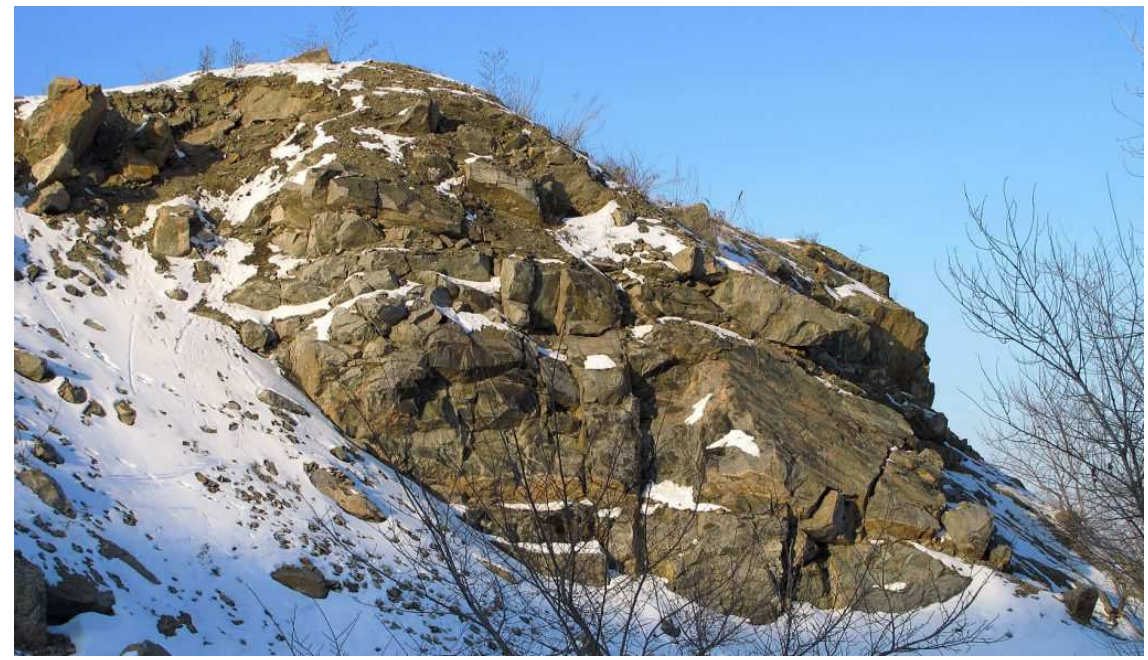

Fig. 16 The Strilcha Zabora near Voloske village. 
The Demurynsky complex also includes concordant and cross-cutting veins and schlieren-like outcrops of aplite-pegmatoide granites among the rocks of different composition. The absolute age of the rocks in the Demurynsky complex is 2.849 bn years.

The Mokromoskovsky complex is represented by palingenesis-anatectic granitoids and migmatites in the branch of the complex on the Right bank of the Dnipro, south of the Redina Ravine. The complex is dominated by aplite-pegmatoide and pegmatoid granites with xenoliths of migmatites. They form separate areas, and numerous veins, schlierens and stocks in the rocks, which enclose them, outside and in the granites of the Mokromoskovsky massif. The largest area of aplite-pegmatoide granites with numerous outcrops is the Tavolzhanske field, along the
Dnipro in the area of Tavolzhansky Island. The main rock-forming minerals are aplite-pegmatoide granites represented by microcline, plagioclase and quartz; secondary rocks are biotite, muscovite, epidote, chlorite, sericite; accessory rocks are represented by ore minerals, apatite, zircon, sphene, titanite, monazite. In the zone of the effect of deep Devladivsky fault, which crosses the north part of the Mokromoskovsky massif, autochthonous two feldspar granitoids were affected by intense tectonicmetasomatic transformations and are often diagnosed as cataclasites and mylonites. According to U$\mathrm{Pb}$ dating, the age of the granites of the Mokromoskovsky complex is $2850-2800$ mil years.

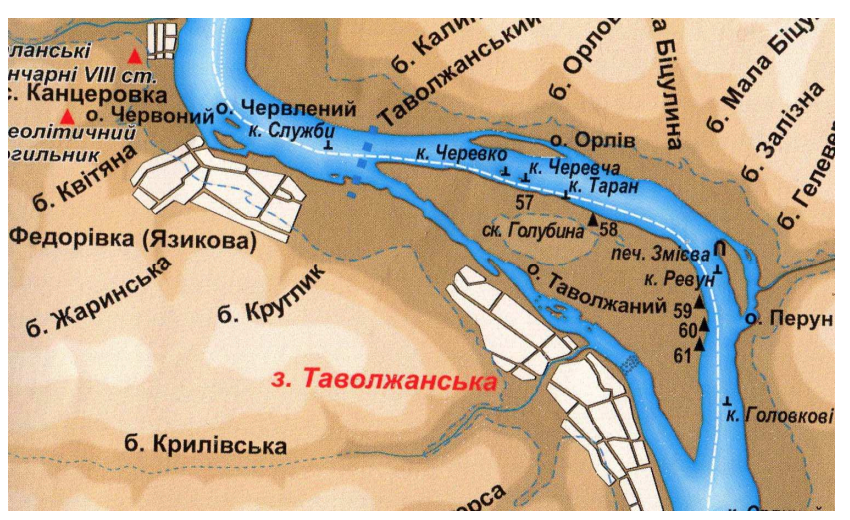

a

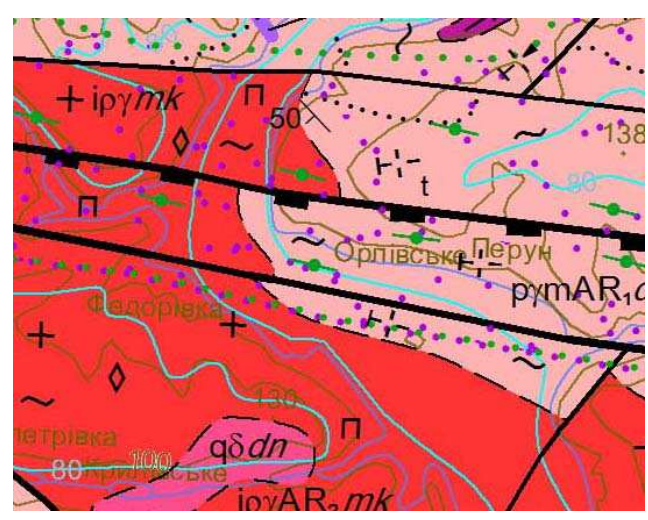

b

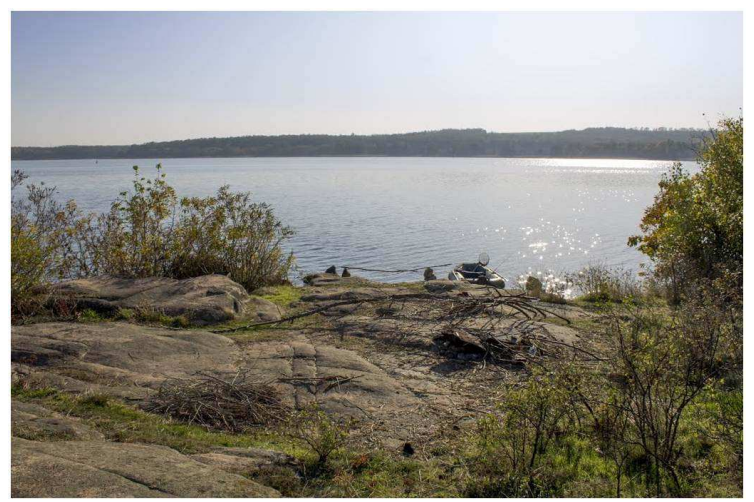

c

Fig. 17 Mokromoskovsky massif on the map of the Rapids (a) and the map of Precambrian rocks, and also the outcrops of aplitepegmatoide granites of the massif on Tavolzhansky Island 

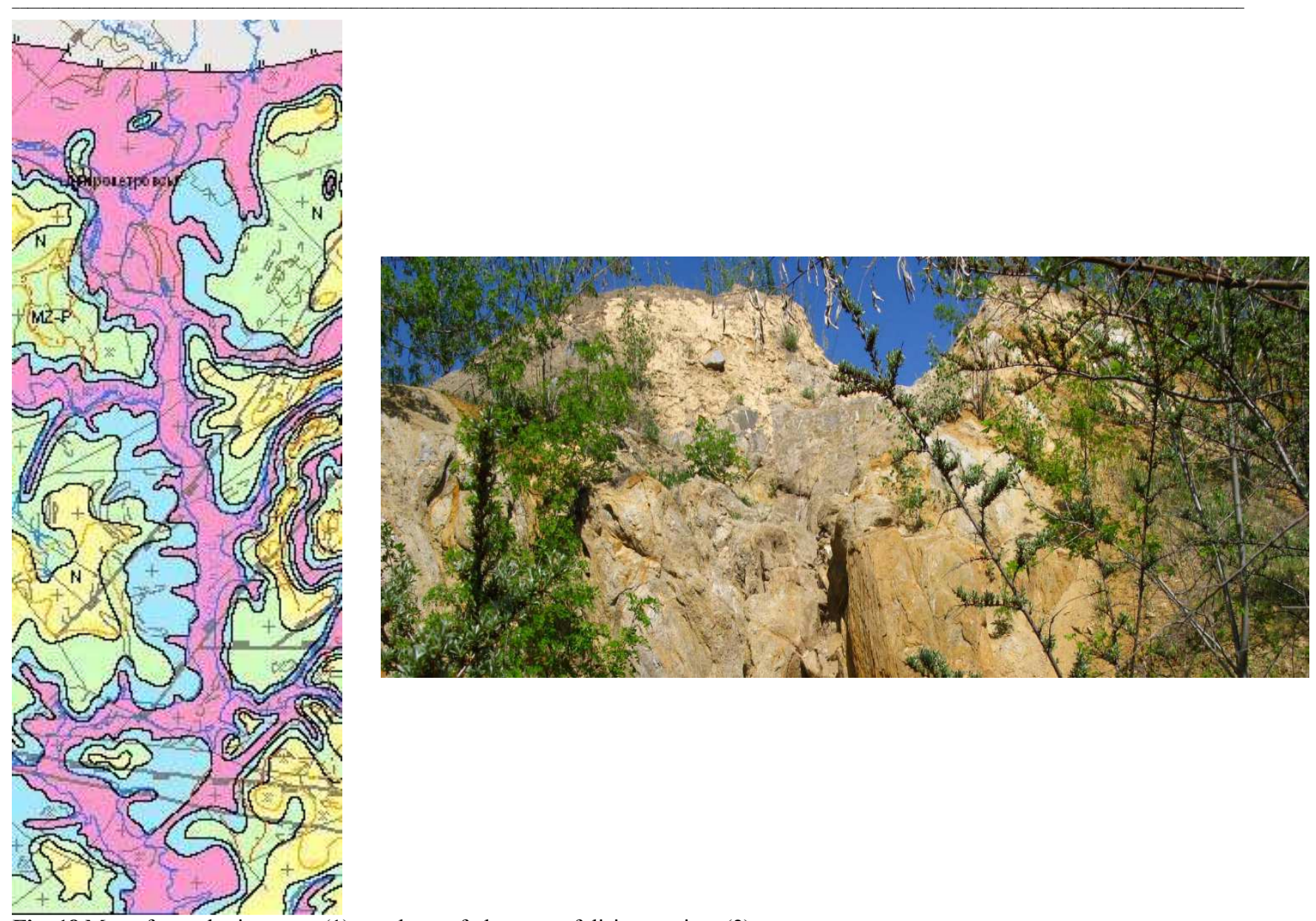

Fig. 18 Map of weathering crust (1), products of the zone of disintegration (2)

A stable tendency towards elevation and the intensive ruination, disintegration, chemical and physical weathering has been affecting the Ukrainian Shield for a long geological period. After the Ukrainian Shield stabilized as a platform structure, during the following period of the development, a profile of the weathering core developed everywhere on its surface. Along the Dnipro, the products of the zone of disintegration of the weathering core are overlapped by sedimentary rocks. In the natural outcrops of the shore zone of the Dnipro, usually only solid and insignificantly weathered crystalline Precambrian rocks occur, whereas the rocks of the weathering core can be found at the bottoms of riverside gullies and ravines. Mostly, these are the products of the zone of disintegration and primary leaching. Also, its insignificant fragments can be found in the quarries of extraction of crystalline rocks (Chaplynsky, Pershotravensky Quarries).

Conclusions. The Dnipro Rapids have provided interest as a natural phenomenon unique for a lowland river since time immemorial. After they were flooded in 1932, they lost their role as an obstacle to the waters of the Dnipro, but not their historical significance. They continued to exist firstly in the memories of the old Dnipro sailing masters and witnesses of their existence, and further in old and new chronicles, narratives, stories, songs, post cards and works of historical literature. Practically no witnesses of the bright past of the Dnipro Rapids are left, but the severe rocky outcrops of the Precambrian crystalline formations, deaf witnesses and close relatives of every Rapid, still rise above the Dnipro. The geoand biodiversity of this territory, fascinating landscapes, the commitment to preserve all this for future generations and not to lose the memory of the historical past of the Rapids are strong reasons for establishing a "Dnipro Rapids" National Park on the territory between the Kodatsky Rapid and the Hortytsia Island. The first steps towards this goal have been already made, therefore in Zaporizhia there are the "Dniprovski Porohy" Geological Reserve of National Significance and the "Dniprovi Porohy" Regional Landscape Park. Further projects will involve diligent work on their unification, enlarging of the protected territory, achieving of a higher status and organizing a National Park of an International Level. The most significant component of the future geopark is definitely its geological element, therefore the priority aim of the park's work will be a full-scale evaluation of the geological heritage and its usage with the purposes of geotourism. 


\section{References}

Boplan y ego opysanye Ukrayny. 2005. [Boplan and his description of Ukraine]. Eastern Literature. Retrieved from: http://www.vostlit.info/Texts/rus12/Boplan/text1.phtml?id=189

Czołowski, A. 1926. Kudak. Przyczynki do założenia i upadku twierdzy. [Notes to the establishment and destruction of the fortress] "Kwartalnik Historyczny" (Historical Quarterly) R., 161-184.

Dolukhanov, P.M. 1996. The Early Slavs: Eastern Europe from the Initial Settlement to the Kievan Rus. Hardcover, Published by Longman Publishing Group, 1- 256

Domger, V.A. 1902. Geologycheskye yssledovanyja v Juzhnoj Rossyy v 1881-1884 godah. [Geological investigations in Southern Russia in 18811884]. Proceedings of the Geological Committee, vol. XX, 1, 1902, 127 - 130.

Javornycky, D.I. 1928. Dniprovi porogy. Al'bom fotografij z geografichno-istorychnym narysom. [Dnieper rapids. Album of photos with a geographic-historical essay]. Reprint: compiler SA Savchuk O.O. , 2016. Preface and Notes Vlasova O.Yu., Kharkov, 1-194.

Jordan, Robert Paul. 1985. "When The Rus Invaded Russia... Viking Trail East". National Geographic. Vol. 167, 278-317.

Kostjantin VII Bagrjanorodnij. 1991. Ob upravlenii imperiej. [About empire management]. (Прóss

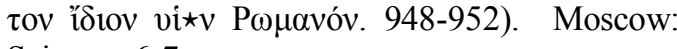
Science, 6-7.

Maryan Dubiecki, 1900. Kudak: twierdza kresowa i jej okolice. [Kudak: the border fortress and its surroundings]. Warszawa, Gebethner i Wolff, 151-152.

Shpyl'chak, V.O., Manyuk, V.V., Sukach, V.V., Nekrjach, A.I. 2007. Derzhavna geologichna karta Ukrai'ny masshtabu 1:200000, arkush M 36 - XXXVI (Dnipropetrovs'k). Central'noukrai'ns'ka serija. [State geological map of Ukraine scale 1: 200000, sheet M - 36 - XXXVI (Dnipropetrovsk). Central Ukrainian series]. Explanatory note. State Geological Survey, SE "Yuzhnukrgeologiya", UkrSGRI, 1-116 (In Ukrainian).

Sukach, V.V. 2007. Subluzhni metamorfizovani gabroi'dy Seredn'ogo Prydniprov'ja. [Subalkalic metamorphosed gabroids of the Middle Dnieper]. Geology and issues of geological mapping and study of the Precambrian formations of the Ukrainian Shield: materials 4 sciences Meeting of geologists-surveyors of Ukraine (October 8-12, 2007, Kryvy Rih). Dnipropetrovsk, 59-62.

Chaban, M. 2010. Above Kodak. This year the unique fortress marks its 375th anniversary. The day weekly digest. Retrieved from: https://day.kyiv.ua/en/article/time-out/abovekodak 